\title{
Increased mortality attributed to Chagas disease: a systematic review and meta-analysis
}

Zulma M. Cucunubá ${ }^{1,2^{*}}$, Omolade Okuwoga', María-Gloria Basáñez ${ }^{1}$ and Pierre Nouvellet ${ }^{1,3}$

\begin{abstract}
Background: The clinical outcomes associated with Chagas disease remain poorly understood. In addition to the burden of morbidity, the burden of mortality due to Trypanosoma cruzi infection can be substantial, yet its quantification has eluded rigorous scrutiny. This is partly due to considerable heterogeneity between studies, which can influence the resulting estimates. There is a pressing need for accurate estimates of mortality due to Chagas disease that can be used to improve mathematical modelling, burden of disease evaluations, and cost-effectiveness studies.
\end{abstract}

Methods: A systematic literature review was conducted to select observational studies comparing mortality in populations with and without a diagnosis of Chagas disease using the PubMed, MEDLINE, EMBASE, Web of Science and LILACS databases, without restrictions on language or date of publication. The primary outcome of interest was mortality (as all-cause mortality, sudden cardiac death, heart transplant or cardiovascular deaths). Data were analysed using a random-effects model to obtain the relative risk (RR) of mortality, the attributable risk percent (ARP), and the annual mortality rates (AMR). The statistic $\mathrm{I}^{2}$ (proportion of variance in the meta-analysis due to study heterogeneity) was calculated. Sensitivity analyses and publication bias test were also conducted.

Results: Twenty five studies were selected for quantitative analysis, providing data on 10,638 patients, 53,346 patient-years of follow-up, and 2739 events. Pooled estimates revealed that Chagas disease patients have significantly higher AMR compared with non-Chagas disease patients ( 0.18 versus 0.10 ; $R R=1.74,95 \% \mathrm{Cl} 1.49-2.03$ ). Substantial heterogeneity was found among studies $\left(I^{2}=67.3 \%\right)$. The ARP above background mortality was $42.5 \%$. Through a sub-analysis patients were classified by clinical group (severe, moderate, asymptomatic). While RR did not differ significantly between clinical groups, important differences in AMR were found: AMR $=0.43$ in Chagas vs. 0.29 in non-Chagas patients ( $R R=1.40,95 \% \mathrm{Cl} 1.21-1.62$ ) in the severe group; $A M R=0.16$ (Chagas) vs. 0.08 (nonChagas) ( $R R=2.10,95 \% \mathrm{Cl} 1.52-2.91$ ) in the moderate group, and $\mathrm{AMR}=0.02$ vs. 0.01 ( $R R=1.42,95 \% \mathrm{Cl} 1.14-1.77$ ) in the asymptomatic group. Meta-regression showed no evidence of study-level covariates on the effect size. Publication bias was not statistically significant (Egger's test $p=0.08$ ).

Conclusions: The results indicate a statistically significant excess of mortality due to Chagas disease that is shared among both symptomatic and asymptomatic populations.

Keywords: Chagas disease, Trypanosoma cruzi, Cardiomyopathy, Survival, Excess mortality, Mortality rate, Relative risk, Attributable risk, Meta-analysis, Heterogeneity

\footnotetext{
* Correspondence: zcucunuba@gmail.com

María-Gloria Basáñez and Pierre Nouvellet are joint last authors.

'London Centre for Neglected Tropical Disease Research (LCNTDR),

Department of Infectious Disease Epidemiology, School of Public Health,

Faculty of Medicine (St Mary's campus), Imperial College London, Norfolk

Place, London W2 1PG, United Kingdom

${ }^{2}$ Grupo de Parasitología - RED CHAGAS, Instituto Nacional de Salud, Bogotá,

Colombia

Full list of author information is available at the end of the article
} 


\section{Background}

Chagas disease is a neglected tropical disease (NTD) of global health concern with around $13 \%$ of the population residing in Latin America considered at risk of Trypanosoma cruzi (Kinetoplastida: Trypanosomatidae) infection. The infection is endemic in 21 countries [1]. Currently, it is estimated that Chagas disease affects between 6 and 8 million individuals, with an attributed number of deaths of approximately 12,000 per year worldwide [2].

Although Chagas disease was first described more than a century ago, the course of the disease and its clinical outcomes are still not well understood [3]. The clinical course of Chagas disease is usually divided into acute and chronic phases. In most cases, the initial infection is asymptomatic. However, a few cases will present acute symptoms and in some instances death may occur $[4,5]$. Infected individuals surviving the acute phase-which is the most common occurrence-enter the indeterminate stage, characterised by a long asymptomatic period before the onset of clinical signs and symptoms. The latter can last 10-30 years or until the end of an individual's life [6]. Based on early cohort studies, an estimated $20-30 \%$ of infected individuals would eventually develop heart disease, with an associated increased mortality $[5,7,8]$. A recent cohort study on infected blood donors in Brazil showed an annual rate of progression to cardiomyopathy of $1.85 \%$ per year [9] and other studies have found that Chagas disease is an independent risk factor for stroke [10, 11]. Although Chagas disease is one of the NTDs globally with a large proportional contribution of years of life lost (YLL) to its total disability-adjusted life years (DALYs) [12], there is a paucity of research measuring rigorously disease progression rates according to the different stages described above and quantifying excess mortality due to Chagas disease compared with mortality rates in non-chagasic individuals.

Processes of extensive inflammation and fibrosis appear to be involved in the physiopathology of the chagasic cardiomyopathy [7]. The clinical manifestations of Chagas disease may be characterised by the grade of myocardial damage [13]. However, although some similarities in clinical presentation occur, there is evidence that Chagas cardiomyopathy has specific characteristics that could influence mortality when compared with other aetiologies or with idiopathic dilated cardiomyopathy [14].

A better understanding of the magnitude of morbidity and mortality associated with Chagas disease is imperative for appropriately measuring burden of disease and evaluating the cost effectiveness of strategies to prevent and control T. cruzi infection and its clinical sequelae. This is because mathematical modelling of infection and disease, ensuing burden of disease quantifications, and accompanying cost-effectiveness studies critically rely on estimates of Chagas disease-related morbidity and mortality rates $[2,15,16]$. However, inspection of the literature reveals a great deal of variation in the reported mortality rates attributed to Chagas disease, raising difficulties of interpretation and hampering their use in model parameterisation.

In 2007, Rassi et al. [17] reviewed predictors of mortality in chronic Chagas disease, reporting annual mortality rates from a selection of papers, which ranged from 0.2 to $19.2 \%$ per year without a control group comparison. More recently, and specifically for sudden death, De Souza et al. [18] found, in a retrospective cohort study, that mortality rates varied according to the clinical severity of the chronic phase, being estimated as $1.5 \%$, $25 \%$, and $51 \%$, for mild, moderate and severe cases, respectively (see also Rassi et al. [19]). The inconsistency of reported rates is likely to be the result of heterogeneity in the clinical presentation of the populations studied. Additionally, Linetzky et al. [20].conducted a systematic review comparing cardiovascular outcomes between Chagas and non-Chagas patients, and reported higher mortality risk in chagasic patients but without quantifying the effect.

In view of the above, the objectives of the present study are: 1) to conduct a systematic review of the literature in order to identify those studies in which mortality was measured for both chagasic and non-chagasic (control) patients, 2) to perform a meta-analysis of such studies in order to derive estimates of risk ratios, attributable risk, and mortality rates associated with Chagas disease, and 3) to provide overall and stage-specific estimates of mortality for further mathematical modelling of the relationship between infection and morbi-mortality, burden of disease estimation and economic evaluations.

\section{Methods}

The PRISMA (Preferred Reporting Items for Systematic Reviews and Meta-Analyses) guidelines and checklist was used to ensure inclusion of relevant information in the analysis [21] (Additional file 1).

\section{Search strategies}

Searches were conducted in PubMed (online version of Index Medicus, produced by the USA National Library of Medicine, NLM); MEDLINE (a subset of PubMed ( 98 \%) made available by NLM); EMBASE (Excerpta Medica dataBASE), Web of Science (Core Collection) and LILACS (Latin American and Caribbean Health database), without time filters until the $31^{\text {st }}$ of September 2015. The search algorithm combined four search terms to represent the grouping of the concepts most relevant to the question under scrutiny: 1) Chagas disease, 2) mortality, 3) progression, and 4) survival analysis. This search algorithm was applied to each database to maintain consistency in the results generated. The full search terms for individual databases are available in 
Additional file 2: Table S1. All the titles and abstracts were assessed by two independent investigators (ZMC and $\mathrm{OO}$ ), eliminating studies that did not meet the inclusion criteria: i. cohort studies, ii) comparing Chagas and non-Chagas patients, iii) with follow-up for more than one year. Disagreements were resolved by consensus, and in the case of persistent disagreement, the full text of the article was examined. References cited in the selected papers were inspected and if appropriate included as secondary searches.

\section{Data extraction}

Each paper that was selected for analysis of the full text was reviewed carefully and the relevant information was extracted. In some instances information was extracted from available data tables or figures, where values were not explicitly mentioned in the text. A data extraction table was designed to obtain information from each eligible study. The following items were included: first author; year of publication; year of study; location of the study; study design; sample size; proportion of men in the study population; age group; mean/median age of study participants; number of deaths; years of follow up; number of persons-year of follow up; loss to follow up (drop-out rate); clinical classification (severe, moderate, asymptomatic); reported effect size and corresponding adjustments.

In order to obtain results accounting for severity of symptoms, the data were extracted and classified according to the clinical severity reported in each study, as follows:

- Severe stage: this stage included patients with cardiac complications, attending health facilities and usually classified according to the New York Heart Association Functional Classification (NYHA) III and IV. Also one study [22] which included only a population under resynchronization therapy was considered in this stage.

- Moderate stage: this included populations mostly classified according to NYHA I and II criteria.

- Asymptomatic/general population: this category included both asymptomatic populations - mainly from population studies - and also individuals with minimal electrocardiogram (ECG) damage or without report of deleterious ejection fraction.

- All stages: this category included studies in which several clinical stages were used in comparison to clinically similar but uninfected controls.

\section{Quality assessment}

The Newcastle-Ottawa Scale (NOS) was used to assess the risk of bias of the studies included in this review in a standardised manner, as this metric is easy to interpret and is recommended for quality assessment by the Cochrane Collaboration [23]. The NOS scale assesses each study on three components, namely, the selection of the study population, a valuation of comparability of the study groups, and an assessment of the outcome of interest. Each study is scored for each component by the award of "stars". The checklist, amendments made to the original scale and details on the assessment for each study are presented in Additional file 2: Table S2. The critical appraisal of the studies was conducted following the data extraction process. Three levels of quality were considered: low, moderate and high. Due to the small number of studies identified, studies were not excluded based on quality assessment. Nevertheless, a separate analysis was done only using papers deemed as of "high quality".

\section{Statistical analysis}

Studies were required to report hazard ratios (HRs), relative risk ratios (RRs), odds ratios (ORs) and their $95 \%$ confidence intervals (CIs) or to provide adequate data to allow the $95 \%$ CI to be calculated. Because not all studies reported deaths in a uniform manner, the analysis is based on all-cause mortality, cardiac death, heart transplant or death due to stroke. For quantitative analysis, studies were included if enough information was provided to estimate crude RRs.

Selected studies differed substantially in terms of sample size, study location and clinical characteristics; therefore, heterogeneity in mortality rates was potentially important. Thus, a random-effects model was used to test differences in rates of mortality between chagasic and non-chagasic populations. For the random-effects model, tau-squared $\left(\tau^{2}\right)$ was presented as a measure of the between-study variance. For comparison, results using a fixed-effects model are also presented (Additional file 2: Figure S1).

Heterogeneity among studies was measured using Cochran's Q test and $\mathrm{I}^{2}$ statistic. Cochran's $\mathrm{Q}$ is computed by summing the squared deviations of each study's estimate from the overall estimate, weighting each study's contribution. The $\mathrm{p}$-values for this test are obtained by comparing the $\mathrm{Q}$ statistic to a chi square distribution with $k-1$ degrees of freedom (df) (where $k$ is the number of studies). The $\mathrm{I}^{2}$ statistic measures the degree of inconsistency in the studies' results. Formally, $\mathrm{I}^{2}=100 \% \times(\mathrm{Q}-\mathrm{df}) / \mathrm{Q}$, measuring the percentage of variation across studies that is due to heterogeneity rather than to chance [24].

To explore further the source of potential heterogeneity in mortality between studies, we used meta-regression techniques to formally identify potential covariates of the estimated effect on mortality rates $[25,26]$. Covariates tested included clinical characteristics (as defined above), starting year of the study, sex (as proportion of males), and location of study (country). 
We explored publication bias by drawing funnel plots, enabling quantification of bias using Egger's regression asymmetry test [27]. Interpretation of funnel plots is facilitated by inclusion of diagonal lines representing the $95 \%$ confidence limits around the summary effect. In the absence of heterogeneity, $95 \%$ of the studies should lie within the funnel defined by these lines (because these are not strictly speaking $95 \%$ limits, they are referred to as "pseudo $95 \%$ confidence limits") [28]. A trim-and-fill technique (aimed both at identifying and correcting funnel plot asymmetry) was then used to re-estimate excess mortality correcting for publication bias (i.e., by incorporating the hypothetically missing studies) [29].

Finally, sensitivity analyses were also performed by 1) sequentially removing one study at a time and reevaluating the model to explore the impact of potential outliers on estimates of excess mortality, and 2) restricting the analysis to 'high quality' papers.

The crude mortality rates were calculated for each clinical group and RR values were used for meta-analysis. Annual mortality rates (AMR) are reported (unless otherwise stated) per person per year. The Attributable Risk Percent (ARP) was used to estimate excess mortality above background mortality rate, as $(R R-1) / R R$ expressed in percent.

All analyses were performed using Stata 13.1 (StataCorp, College Station, TX).

\section{Results}

Description of included studies and data obtained

The systematic literature search (Fig. 1), yielded 6523 distinct publications, which were identified and reviewed. After exclusions, 31 entries were selected for inclusion for qualitative analysis. Twenty seven out of the 31 studies were conducted in Brazil; the remaining four were conducted in Bolivia, Chile, United States of America, and Venezuela, each country contributing one study. A total of six studies were excluded from quantitative analysis due to these reports either not providing enough information in the paper [30-32], the outcome was not clearly measured as part of the study $[33,34]$ or due to the absence of deaths during the follow-up period [35]. A total of 25 were selected for quantitative meta-analysis, of which 12 (48 \%) were classified as of high quality, $11(44 \%)$ as of moderate quality, and 2 $(8 \%)$ as of low quality. Detailed results on quality assessment of the 25 studies are presented in Additional file 2: Table S2. These studies yielded data on 10,638 patients, 53,346 patient-years of follow-up, and 2739 events.

Only 17 out of the selected 25 studies provided actual metrics for the relationship between Chagas disease and death, all of them reporting a positive effect (RR, HR or OR greater than 1). Only 9 of these studies adjusted for covariates such as age, sex, other risk factors, schooling,

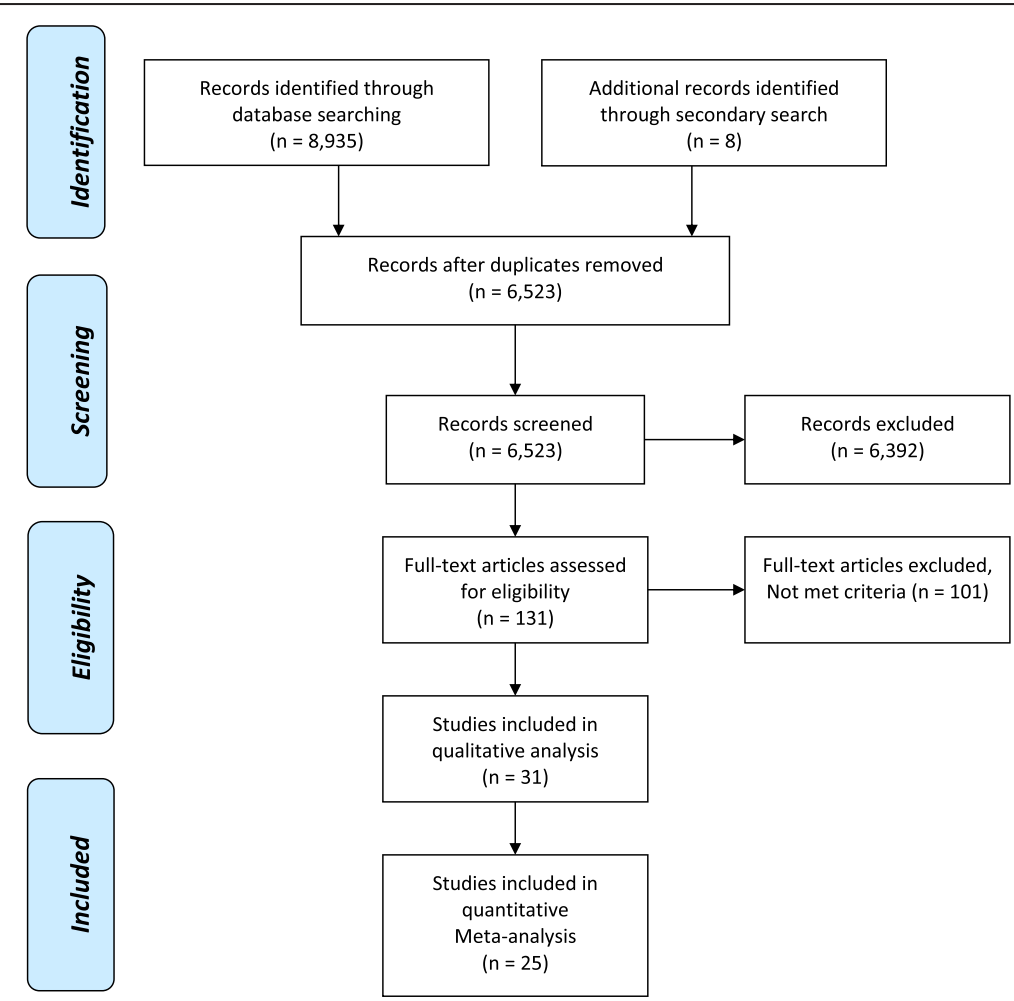

Fig. 1 Flow diagram describing the selection of studies included in the meta-analysis 
etc. The complete list of studies included in the quantitative analysis is provided in Table 1.

\section{Pooled estimates}

When pooling all studies, the overall RR was 1.74 (95\% CI 1.49-2.03. This RR reflects the overall excess mortality for chagasic patients compared with similar controls regardless of their clinical presentation. The corresponding overall annual mortality rate (AMR) was 0.18 among the chagasic groups versus 0.10 among the control groups. The observed $\mathrm{I}^{2}$ statistic showed substantial heterogeneity among studies $\left(\mathrm{I}^{2}=67.3 \%, \tau^{2}=0.07, p<0.01\right)$ (Fig. 2). Results were similar for a fixed-effects model (Additional file 2: Figure S1) confirming the robustness of our conclusions. The value of ARP above the overall background mortality rate was estimated to be $42.5 \%$.

\section{Exploring heterogeneity}

The contribution of study heterogeneity varied between clinical groups, with the greatest heterogeneity being exhibited in the clinical presentation category that included all stages $\left(\mathrm{I}^{2}=83 \%, p<0.01\right)$. The heterogeneity present in the moderate and severe category was lower and not statistically significant $\left(\mathrm{I}^{2}=47.1 \%, p=0.07\right.$ and $\mathrm{I}^{2}=$ $42.8 \%, p=0.12$ respectively). The lowest degree of heterogeneity was present among the asymptomatic cases $(14.7 \%, p=0.32)$. Figure 2 and Additional file 2: Table S3 present detailed results.

While there was clear evidence of differences in terms of AMRs between disease groups, the magnitude of excess mortality among chagasic patients, measured by the RRs, did not differ significantly between clinical groups. For the severe clinical group, AMR was 0.43 in the patients with Chagas versus 0.29 in the nonChagas patients $(R R=1.40,95 \%$ CI 1.21-1.62). For the moderate clinical group the corresponding AMR values were 0.16 versus 0.08 ( $R R=2.10$, $95 \%$ CI 1.52 2.91) and for the asymptomatic/general population category AMR was 0.02 (in Chagas disease patients) versus 0.01 in non- $(\mathrm{RR}=1.42,95 \% \mathrm{CI} 1.14-1.77)$.

Meta-regression on other covariates showed no evidence of significant confounding factors when adjusting for clinical classification, starting year of the study, proportion of males included, and location (country) of the study. However, sufficient information to conduct the meta-regression analysis was only available in 19 out of 25 selected studies. These results are summarised in Additional file 2: Table S4. No further investigation of the impact of sub-groups was feasible due to the small number of studies available.

\section{Publication bias analysis and sensitivity analysis}

Publication bias was explored firstly by looking at funnel plots (Fig. 3). The relative lack of symmetry among small-sample studies indicated a potential bias, consistent with small studies failing to report negative results. Although this bias was not significant using the Egger's test $(p=0.08)$, we used trim-and-fill methodology (Additional file 2: Figures S2 and S3) to correct for this potential bias, re-estimating the overall excess mortality. Initial estimates were robust to publication bias, and after correction the overall RR decreased only slightly to $1.4295 \%$ CI 1.19-1.70.

In the sensitivity analysis, the point and uncertainty estimates of the RR remained unaffected by removing in turn a single study (Additional file 2: Figure S4), leading to the conclusion that no outliers were present in our study selection. Finally, using only the "high quality" papers yielded a $\mathrm{RR}=2.07$ (95\% CI 1.54-2.78), emphasizing the robustness of our results and suggesting a low impact of the quality of studies on the estimated excess mortality values (Additional file 2: Figure S5).

\section{Discussion}

Our study is the first to review, collate and analyse available (published) studies on mortality rates associated with Chagas disease using a robust and coherent metaanalytical framework. One of the motivations for this meta-analysis was to assess whether Chagas disease induces a higher risk of mortality compared to control populations with similar clinical symptoms. The overall excess mortality, estimated as a relative risk ratio, was equal to 1.74 (95\% CI 1.49-2.03), which was robust to both publication bias ( $R R=1.42,95 \%$ CI 1.19-1.70) and highest quality studies ( $R R=2.07,95 \%$ CI 1.54-2.78).

Interestingly, this (statistically significant) magnitude of excess mortality appeared to affect equally patients with mild, moderate or severe symptoms (relative to their baseline, background mortality). By contrast, AMRs increased with clinical severity, from 0.02 in asymptomatics to 0.43 in those with severe symptoms (in Chagas patients), whereas AMR values ranged from 0.01 in asymptomatics to 0.29 in those with severe disease but without Chagas disease.

We found no significant impact of sex and study location (country) on excess mortality. However, larger studies that have focused only on cohorts of chagasic patients, consistently report men as being at increased risk of cardiac disease and death $[9,36]$. Country of study may reflect a differential distribution of $T$. cruzi genotypes, and these are believed to influence disease progression and hence mortality [37]. The fact that no effect of country was found in our study may be due to the relatively limited number of studies with informative data available and their small sample sizes. It may also be possible that although disease progression rates may indeed be influenced by country (proxy for T. cruzi 
Table 1 Characteristics of the 25 studies included in the meta-analysis of Chagas disease-associated mortality

\begin{tabular}{|c|c|c|c|c|c|c|c|c|c|c|c|c|c|c|}
\hline \multirow{2}{*}{$\begin{array}{l}\text { First } \\
\text { author, } \\
\text { year [Ref] }\end{array}$} & \multirow[t]{2}{*}{ Country } & \multirow{2}{*}{ Outcome } & \multirow{2}{*}{$\begin{array}{l}\text { Study } \\
\text { period }\end{array}$} & \multirow{2}{*}{$\begin{array}{l}\text { Diagnostic } \\
\text { test }\end{array}$} & \multirow[t]{2}{*}{ Population type } & \multirow[t]{2}{*}{ Control group } & \multirow{2}{*}{$\begin{array}{l}\text { Mode of } \\
\text { death }\end{array}$} & \multirow{2}{*}{$\begin{array}{l}\text { Disease } \\
\text { classification }\end{array}$} & \multirow{2}{*}{$\begin{array}{l}\text { Sample } \\
\text { size } \\
\\
\text { exp/ } \\
\text { non- } \\
\text { exp }\end{array}$} & \multirow{2}{*}{$\begin{array}{l}\text { Outcome } \\
\text { exp/non- } \\
\exp \end{array}$} & \multirow{2}{*}{$\begin{array}{l}\text { Person- } \\
\text { yrs of } \\
\text { follow } \\
\text { up } \\
\text { exp/ } \\
\text { non- } \\
\text { exp }\end{array}$} & \multirow{2}{*}{$\begin{array}{l}\text { Crude } \\
\text { RR }\end{array}$} & \multicolumn{2}{|c|}{ Reported effect estimate } \\
\hline & & & & & & & & & & & & & $\begin{array}{l}\text { Estimate } \\
(95 \% \mathrm{Cl})\end{array}$ & $\begin{array}{l}\text { Adjusted by } \\
\text { variables }\end{array}$ \\
\hline $\begin{array}{l}\text { Coura, } \\
1985[51]\end{array}$ & Brazil & Death & $\begin{array}{l}1974- \\
1984\end{array}$ & Serology & $\begin{array}{l}\text { General population } \\
\text { endemic area } \\
\text { (included } \\
\text { undetermined and } \\
\text { cardio-myopathy) }\end{array}$ & $\begin{array}{l}\text { Same population but } \\
\text { uninfected }\end{array}$ & $\begin{array}{l}\text { Cardio- } \\
\text { myopathy }\end{array}$ & All stages & $235 / 216$ & $54 / 23$ & $\begin{array}{l}2350 / \\
2160\end{array}$ & 2.16 & $\begin{array}{l}2 \text { times } \\
\text { higher } \\
\text { (NR) }\end{array}$ & NR \\
\hline $\begin{array}{l}\text { Pereira, } \\
1985 \text { [52] }\end{array}$ & Brazil & Death & $\begin{array}{l}1976- \\
1980\end{array}$ & IFAT \& CF & $\begin{array}{l}\text { General population - } \\
\text { Municipality La Lapa }\end{array}$ & $\begin{array}{l}\text { General population - } \\
\text { same municipality }\end{array}$ & SD (64.7\%) & $\begin{array}{l}\text { Asymptomatic/ } \\
\text { GenP }\end{array}$ & 192/188 & $22 / 6$ & $\begin{array}{l}1152 / \\
1128\end{array}$ & 3.59 & $N R(N R)$ & NR \\
\hline $\begin{array}{l}\text { Maguire, } \\
1987 \text { [53] }\end{array}$ & Brazil & Death & $\begin{array}{l}1974- \\
1980\end{array}$ & $\begin{array}{l}\text { IFAT \& CF } \\
\& \text { ELISA }\end{array}$ & $\begin{array}{l}\text { Asymptomatic from } \\
\text { rural Brazilian } \\
\text { community. Normal } \\
\text { ECG }\end{array}$ & $\begin{array}{l}\text { Asymptomatic from } \\
\text { rural Brazilian } \\
\text { community. Normal } \\
\text { ECG }\end{array}$ & NR & $\begin{array}{l}\text { Asymptomatic/ } \\
\text { GenP }\end{array}$ & $40 / 116$ & $3 / 3$ & $\begin{array}{l}949 / \\
771\end{array}$ & 0.81 & $\begin{array}{l}\mathrm{RR}=1.8 \\
(0.8-4.2)\end{array}$ & NR \\
\hline $\begin{array}{l}\text { Mota, } 1990 \\
{[54]}\end{array}$ & Brazil & Death & $\begin{array}{l}1974- \\
1983\end{array}$ & $\begin{array}{l}\text { IFAT \& CF } \\
\& \text { ELISA }\end{array}$ & Rural population & $\begin{array}{l}\text { Rural population, } \\
\text { slightly healthier }\end{array}$ & NR & $\begin{array}{l}\text { Asymptomatic/ } \\
\text { GenP }\end{array}$ & $488 / 509$ & $34 / 28$ & $\begin{array}{l}3842 / \\
3663\end{array}$ & 1.16 & $\begin{array}{l}\mathrm{RR}=1.1 \\
(\mathrm{NR})\end{array}$ & Age adjusted \\
\hline $\begin{array}{l}\text { Bestetti \& } \\
\text { Muccillo, } \\
1997 \text { [8] }\end{array}$ & Brazil & $\begin{array}{l}\text { Cardiac } \\
\text { death }\end{array}$ & $\begin{array}{l}1990- \\
1993\end{array}$ & NR & $\begin{array}{l}\text { Left ventricular } \\
\text { dilatation in ECG. } \\
\text { Cardiomegaly in the } \\
\text { chest X-ray. With or } \\
\text { without symptoms }\end{array}$ & $\begin{array}{l}\text { Similar, uninfected. } \\
\text { HTA 34\% }\end{array}$ & SD (38\%) & $\begin{array}{l}\text { Moderate } \\
\text { stage }\end{array}$ & $75 / 50$ & $21 / 3$ & $\begin{array}{l}225 / \\
150\end{array}$ & 4.67 & $\begin{array}{l}\mathrm{OR}=6.1 \\
(1.7- \\
21.7)\end{array}$ & Not adjusted \\
\hline $\begin{array}{l}\text { Pimenta \& } \\
\text { Valente, } \\
1999 \text { [55] }\end{array}$ & Brazil & $\begin{array}{l}\text { Cardiac } \\
\text { death }\end{array}$ & $\begin{array}{l}1977 \\
1996\end{array}$ & $\begin{array}{l}\text { CF \& IFAT } \\
\& H A I\end{array}$ & $\begin{array}{l}\text { Asymptomatic } \\
\text { individuals with } \\
\text { bundle branch block } \\
\text { (RBBB }=98.2 \%)\end{array}$ & $\begin{array}{l}\text { Sclerosis of the } \\
\text { conducting system of } \\
\text { the heart (Lev- } \\
\text { Lenègre's disease) } \\
\text { (RBBB: } 48.3 \% \text { ) }\end{array}$ & SD (50\%) & $\begin{array}{l}\text { Asymptomatic/ } \\
\text { GenP }\end{array}$ & $55 / 29$ & $17 / 3$ & $\begin{array}{l}554 / \\
229\end{array}$ & 2.34 & NR (NR) & NR \\
\hline $\begin{array}{l}\text { Freitas, } \\
2005 \text { [56] }\end{array}$ & Brazil & Death & $\begin{array}{l}1991- \\
2000\end{array}$ & Serology & NYHA III or IV & IDC & NR & Severe stage & $242 / 454$ & 110/156 & $\begin{array}{l}516 / \\
968\end{array}$ & 1.32 & $\begin{array}{l}H R=1.63 \\
(1.10- \\
1.43)\end{array}$ & $N R$ \\
\hline $\begin{array}{l}\text { Oliveira, } \\
2005 \text { [57] }\end{array}$ & Brazil & Death & $\begin{array}{l}1993- \\
1995\end{array}$ & NR & $\begin{array}{l}\text { Systolic ventricular } \\
\text { dysfunction (LVEF } \\
<55 \% \text { ) at the day of } \\
\text { hospitalisation. } \\
\text { Chagas in } 44 \% \text { of } \\
\text { patients }\end{array}$ & $\begin{array}{l}\text { Any aetiology } \\
\text { identified }\end{array}$ & NR & Severe stage & $56 / 70$ & $50 / 51$ & $71 / 89$ & 1.23 & $\begin{array}{l}\mathrm{RR}=2.66 \\
(1.10- \\
6.46)\end{array}$ & Not adjusted \\
\hline $\begin{array}{l}\text { De } \\
\text { Campos } \\
\text { Lopes, } \\
2006[49]\end{array}$ & Brazil & $\begin{array}{l}\text { Cardiac } \\
\text { death }\end{array}$ & $\begin{array}{l}1998- \\
2000\end{array}$ & NR & $\begin{array}{l}\text { Severe HF; } \\
\text { hospitalized } \\
\text { subsequent-ly. HT } \\
\text { was considered a } \\
\text { censored event }\end{array}$ & $\begin{array}{l}\text { Hospitalized from the } \\
\text { same clinic }\end{array}$ & NR & Severe stage & $102 / 392$ & $72 / 169$ & $\begin{array}{l}204 / \\
784\end{array}$ & 1.64 & NR (NR) & $\begin{array}{l}\text { Age and } \\
\text { controlled for } \\
\text { relevant } \\
\text { covariates: } \\
\text { health system, } \\
\text { myocardial } \\
\text { infarction, HTA }\end{array}$ \\
\hline
\end{tabular}


Table 1 Characteristics of the 25 studies included in the meta-analysis of Chagas disease-associated mortality (Continued)

\begin{tabular}{|c|c|c|c|c|c|c|c|c|c|c|c|c|c|c|}
\hline $\begin{array}{l}\text { Heringer- } \\
\text { Walther, } \\
2006 \text { [58] }\end{array}$ & Brazil & $\begin{array}{l}\text { Cardiac } \\
\text { death or } \\
\text { HT }\end{array}$ & $\begin{array}{l}2001- \\
2006\end{array}$ & $\begin{array}{l}2 \text { positive } \\
\text { serologies }\end{array}$ & $\begin{array}{l}\text { Dilated cardio- } \\
\text { myopathy. All stages }\end{array}$ & $\begin{array}{l}\text { Idiopathic dilated } \\
\text { cardio-myopathy. } \\
\text { Other structural } \\
\text { cardiac diseases and } \\
\text { comor-bidities were } \\
\text { excluded in both } \\
\text { groups }\end{array}$ & NR & All stages & $274 / 504$ & $8 / 10$ & $\begin{array}{l}716 / \\
1108\end{array}$ & 1.24 & $\begin{array}{l}\mathrm{OR}=3.34 \\
(1.90- \\
5.89)\end{array}$ & NR \\
\hline $\begin{array}{l}\text { Braga, } \\
2008[59]\end{array}$ & Brazil & Death & $\begin{array}{l}2003- \\
2004\end{array}$ & NR & $\begin{array}{l}\text { HF and moderate to } \\
\text { severe left ventricle } \\
\text { systolic dysfunction }\end{array}$ & $\begin{array}{l}\text { Other aetiologies not } \\
\text { specified }\end{array}$ & NR & $\begin{array}{l}\text { Moderate } \\
\text { stage }\end{array}$ & $89 / 102$ & $16 / 10$ & $89 / 102$ & 1.83 & $\begin{array}{l}\mathrm{OR}=1.67 \\
(0.67- \\
4.41)\end{array}$ & Education level \\
\hline $\begin{array}{l}\text { Silva, } 2008 \\
\text { [60] }\end{array}$ & Brazil & Death & NR & NR & $\begin{array}{l}\text { Admitted for } \\
\text { decom-pensated HF. } \\
\text { NYHA III-IIV }\end{array}$ & Other aetiologies & NR & Severe stage & $122 / 232$ & $84 / 111$ & $\begin{array}{l}122 / \\
232\end{array}$ & 1.44 & $N R(N R)$ & NR \\
\hline $\begin{array}{l}\text { Lima-Costa } \\
\text { 2010a [61] }\end{array}$ & Brazil & Death & $\begin{array}{l}1997- \\
2007\end{array}$ & $\begin{array}{l}\text { HAI \& } 2 \\
\text { ELISA tests }\end{array}$ & $\begin{array}{l}\text { Bambui, general >60 } \\
\text { years age }\end{array}$ & $\begin{array}{l}\text { General population > } \\
60 \text { years age }\end{array}$ & NR & $\begin{array}{l}\text { Asymptomatic/ } \\
\text { GenP }\end{array}$ & $524 / 874$ & $257 / 310$ & $\begin{array}{l}4569 / \\
7621\end{array}$ & 1.38 & $\begin{array}{l}N R \\
p<0.01\end{array}$ & $\begin{array}{l}\text { Age, sex, and a } \\
\text { number of risk } \\
\text { factors }\end{array}$ \\
\hline $\begin{array}{l}\text { Lima- } \\
\text { Costa, } \\
\text { 2010b [50] }\end{array}$ & Brazil & Stroke & $\begin{array}{l}1997- \\
2007\end{array}$ & $\begin{array}{l}\text { HAI \& } 2 \\
\text { ELISA tests }\end{array}$ & $\begin{array}{l}\text { Bambui, general } \\
\text { population }>60 \\
\text { years age (RBBB in } \\
23.5 \% \text {, in schooled }= \\
20 \% \text { ) }\end{array}$ & $\begin{array}{l}\text { General population > } \\
60 \text { years of age and } \\
\text { significantly healthier } \\
\text { than chagasic patients } \\
\text { (RBBB in } 3.3 \% \text { ) and } \\
\text { schooled (50\%) }\end{array}$ & Stroke & $\begin{array}{l}\text { Asymptomatic/ } \\
\text { GenP }\end{array}$ & $563 / 915$ & $20 / 25$ & $\begin{array}{l}3479 / \\
6261\end{array}$ & 1.40 & $\begin{array}{l}H R=1.56 \\
(1.32- \\
1.85)\end{array}$ & $\begin{array}{l}\text { Age, sex, } \\
\text { schooling, } \\
\text { other risk } \\
\text { factors and C- } \\
\text { reactive protein } \\
\text { level }\end{array}$ \\
\hline $\begin{array}{l}\text { Nunes, } \\
2010 \text { [62] }\end{array}$ & Brazil & $\begin{array}{l}\text { Cardiac } \\
\text { death or } \\
\text { HT }\end{array}$ & $\begin{array}{l}1999- \\
2008\end{array}$ & NR & $\begin{array}{l}\text { HF, dilated cardio- } \\
\text { myopathy } \\
\text { (diameter/ body } \\
\text { surface area } \geq 31 \\
\mathrm{~mm} \text { ) and LVEF } \\
<55 \% \text {. NYHA III/IV in } \\
\text { 25\% }\end{array}$ & $\begin{array}{l}\text { Same criteria but } \\
\text { Idiopathic dilated } \\
\text { cardio-myopathy } \\
\text { (NYHA III/IV 27\%) }\end{array}$ & $\begin{array}{l}\text { Progressive } \\
\text { HF (48\%). } \\
\text { SD (42\%) }\end{array}$ & $\begin{array}{l}\text { Moderate } \\
\text { stage }\end{array}$ & $224 / 63$ & $91 / 22$ & $\begin{array}{l}737 / \\
207\end{array}$ & 1.16 & $\begin{array}{l}H R=2.35 \\
(1.25- \\
4.44)\end{array}$ & NR \\
\hline $\begin{array}{l}\text { Issa, } 2010 \\
{[40]}\end{array}$ & Brazil & $\begin{array}{l}\text { Death or } \\
\text { HT }\end{array}$ & $\begin{array}{l}1999- \\
2000\end{array}$ & $\begin{array}{l}\text { IFAT \& HAI } \\
\text { \& ELISA }\end{array}$ & $\begin{array}{l}\text { Clinical trial. } \\
\text { Irreversible chronic } \\
\text { HF of at least 6- } \\
\text { month duration }\end{array}$ & $\begin{array}{l}\text { Other aetiologies, not } \\
\text { specified }\end{array}$ & NR & All stages & $68 / 388$ & $49 / 180$ & $\begin{array}{l}250 / \\
1428\end{array}$ & 1.55 & $N R(N R)$ & $\begin{array}{l}\text { Cox } \\
\text { proportional } \\
\text { hazards } \\
\text { regression } \\
\text { model }\end{array}$ \\
\hline $\begin{array}{l}\text { Cardoso, } \\
2010[63]\end{array}$ & Brazil & Death & $\begin{array}{l}2006- \\
2007\end{array}$ & $\begin{array}{l}\text { ELISA \& } \\
\text { IFAT }\end{array}$ & $\begin{array}{l}\text { NYHA IV, admitted; } \\
\text { poor perfusion and } \\
\text { congestion. (LVEF) < } \\
45.0 \%\end{array}$ & $\begin{array}{l}\text { HTA, Idiopathic, } \\
\text { vasculopathic; alcohol } \\
\text { cardiomyopathy }\end{array}$ & $\begin{array}{l}\text { Progressive } \\
\mathrm{HF}\end{array}$ & Severe stage & $33 / 67$ & $22 / 24$ & $68 / 139$ & 1.87 & $\begin{array}{l}\mathrm{HR}=2.48 \\
(1.28- \\
4.78)\end{array}$ & $\begin{array}{l}\text { Multi-variate } \\
\text { analysis }\end{array}$ \\
\hline $\begin{array}{l}\text { Conceição- } \\
\text { Souza, } \\
2010 \text { [64] }\end{array}$ & Brazil & Death & $\begin{array}{l}2008^{-} \\
2010\end{array}$ & NR & $\begin{array}{l}(\text { LVEF })<45.0 \% \\
\text { Onset of } \\
\text { symptoms }>1 \text { month }\end{array}$ & $\begin{array}{l}\text { Same criteria and } \\
\text { excluded co- } \\
\text { morbidities }\end{array}$ & NR & $\begin{array}{l}\text { Moderate } \\
\text { stage }\end{array}$ & $100 / 62$ & $6 / 2$ & $100 / 62$ & 1.86 & $N R(N R)$ & NR \\
\hline \multirow[t]{2}{*}{$\begin{array}{l}\text { Cruz, } 2010 \\
{[65]}\end{array}$} & Brazil & $\begin{array}{l}\text { Cardiac } \\
\text { death }\end{array}$ & NR & NR & $\begin{array}{l}\text { HF; clinics, patients } \\
\text { under maximal } \\
\text { tolerated medical } \\
\text { treatment }\end{array}$ & $\begin{array}{l}\text { IDC (33\%), HTA (13\%), } \\
\text { ischemic (12\%) }\end{array}$ & $\begin{array}{l}\text { SD and } \\
\text { progressive } \\
\text { HF }\end{array}$ & $\begin{array}{l}\text { Moderate } \\
\text { stage }\end{array}$ & $21 / 55$ & $7 / 11$ & $23 / 61$ & 1.69 & \multirow[t]{2}{*}{$\begin{array}{l}\mathrm{RR}=2.75 \\
(1.35- \\
5.63)\end{array}$} & NR \\
\hline & Brazil & & & Serology & & & $N R$ & & 246/106 & 109/16 & & 2.932 & & \\
\hline
\end{tabular}


Table 1 Characteristics of the 25 studies included in the meta-analysis of Chagas disease-associated mortality (Continued)

\begin{tabular}{|c|c|c|c|c|c|c|c|c|c|c|c|c|c|c|}
\hline $\begin{array}{l}\text { Barbosa, } \\
2011[66]\end{array}$ & & $\begin{array}{l}\text { Death or } \\
\text { HT }\end{array}$ & $\begin{array}{l}2000- \\
2008\end{array}$ & & $\begin{array}{l}\text { LVEF }<55 \% \text { in ECG } \\
\text { or }<50 \% \text { on Radio- } \\
\text { nuclide } \\
\text { ventriculography }\end{array}$ & $\begin{array}{l}\text { IDC with same ECG } \\
\text { criteria and in the } \\
\text { absence of } \\
\text { concomitant } \\
\text { obstructive coronary } \\
\text { artery disease }\end{array}$ & & $\begin{array}{l}\text { Moderate } \\
\text { stage }\end{array}$ & & & $\begin{array}{l}574 / \\
247\end{array}$ & & $\begin{array}{l}H R=3.29 \\
(1.89- \\
5.73)\end{array}$ & $\begin{array}{l}\text { Cox } \\
\text { proportional } \\
\text { hazards model } \\
\text { multi-variate } \\
\text { analysis }\end{array}$ \\
\hline $\begin{array}{l}\text { Ayub- } \\
\text { Ferreira, } \\
2013 \text { [39] }\end{array}$ & Brazil & Death & $\begin{array}{l}1999- \\
2010\end{array}$ & $\begin{array}{l}\text { ELISA \& } \\
\text { IFAT \& HAI }\end{array}$ & $\begin{array}{l}\text { Clinical trial. Chagas } \\
\text { All stages }\end{array}$ & $\begin{array}{l}\text { Similar but uninfected. } \\
\text { Mixed aetiology, not } \\
\text { specified }\end{array}$ & $\begin{array}{l}\text { SD (14.5\%), } \\
\text { HF (22.2\%) }\end{array}$ & All stages & $55 / 287$ & $31 / 29$ & $\begin{array}{l}196 / \\
1024\end{array}$ & 5.58 & $\begin{array}{l}H R=2.76 \\
(1.34- \\
5.6)\end{array}$ & NR \\
\hline $\begin{array}{l}\text { Bestetti, } \\
2013[67]\end{array}$ & Brazil & Death & $\begin{array}{l}2000- \\
2008\end{array}$ & Serology & Chronic systolic HF & $\begin{array}{l}\text { Same criteria for } \\
\text { systemic HTA and } \\
\text { chronic systolic heart } \\
\text { failure }\end{array}$ & NR & $\begin{array}{l}\text { Moderate } \\
\text { stage }\end{array}$ & $244 / 130$ & $185 / 35$ & $\begin{array}{l}1220 / \\
650\end{array}$ & 2.82 & $\begin{array}{l}\mathrm{HR}=2.2 \\
(1.47- \\
3.40)\end{array}$ & $\begin{array}{l}\text { Cox } \\
\text { proportional } \\
\text { hazard model } \\
\text { adjusted for } \\
\text { confounders }\end{array}$ \\
\hline $\begin{array}{l}\text { Peixoto, } \\
2015 \text { [22] }\end{array}$ & Brazil & Death & $\begin{array}{l}2005- \\
2012\end{array}$ & NR & $\begin{array}{l}\text { Patients under } \\
\text { cardiac } \\
\text { resynchronization } \\
\text { therapy; mean LVEF } \\
=25.3\end{array}$ & $\begin{array}{l}\text { Same characteristics } \\
\text { but Ischemic and } \\
\text { idiopathic aetiologies }\end{array}$ & NR & Severe stage & $115 / 311$ & $86 / 111$ & $\begin{array}{l}310 / \\
839\end{array}$ & 2.10 & $N R(N R)$ & NR \\
\hline $\begin{array}{l}\text { Traina, } \\
2015 \text { [68] }\end{array}$ & $\begin{array}{l}\text { USA } \\
\text { and } \\
\text { CA }^{a}\end{array}$ & $\begin{array}{l}\text { Death or } \\
\text { HT }\end{array}$ & $\begin{array}{l}2007- \\
2010\end{array}$ & $\begin{array}{l}\text { IFAT \& } \\
\text { ELISA }\end{array}$ & $\begin{array}{l}\text { Cardio-myopathy } \\
\text { with left ventricular } \\
\text { ejection fraction } \\
\text { (LVEF of } \leq 40 \% \text { ) and } \\
\text { previous residence } \\
\text { in Latin America }\end{array}$ & $\begin{array}{l}\text { Any aetiology } \\
\text { identified }\end{array}$ & NR & $\begin{array}{l}\text { Moderate } \\
\text { stage }\end{array}$ & $25 / 110$ & $9 / 11$ & $42 / 209$ & 4.07 & $\begin{array}{l}H R=4.46 \\
(1.8- \\
10.8)\end{array}$ & Un-adjusted \\
\hline $\begin{array}{l}\text { Sherbuk, } \\
2015 \text { [69] }\end{array}$ & Bolivia & Death & $\begin{array}{l}2012- \\
2013\end{array}$ & $\begin{array}{l}\text { ELISA \& } \\
\text { HAI \& } \\
\text { TESA blot }\end{array}$ & $\begin{array}{l}\text { From asymptomatic } \\
\text { to severe cases }\end{array}$ & $\begin{array}{l}\text { Similar stages but } \\
\text { uninfected }\end{array}$ & NR & All stages & $160 / 60$ & $23 / 4$ & $\begin{array}{l}394 / \\
462\end{array}$ & 2.42 & $\begin{array}{l}\mathrm{HR}=1.78 \\
(1.19- \\
2.65)\end{array}$ & NR \\
\hline
\end{tabular}

ID identification; exp exposed (Chagas-positive); non-exp non-exposed (Chagas-negative); Crude RR crude relative risk estimated manually form the data in the paper; $95 \% C l$ 95\% Confidence Interval; $H R$ hazard ratio; $O R$ odds ratio; CF complement fixation test; ELISA Enzyme-Linked Immunosorbent Assay; HAl hemagglutination inhibition test; IFAT immunofluorescent test; TESA Trypanosoma cruzi excreted-secreted antigens blot; LVEF left ventricular ejection fraction; $E C G$ electrocardiogram; RBBB right bundle branch block; IDC idiopathic dilated cardiomyopathy; HF heart failure; $H T$ heart transplant; $H T A$ arterial hypertension; $S D$ sudden death; Gen $P$ general population; NYHA New York Heart Association Functional Classification; NR not reported. ${ }^{a} C A$ Central America $90 \%$. The references are as appear on the main text 


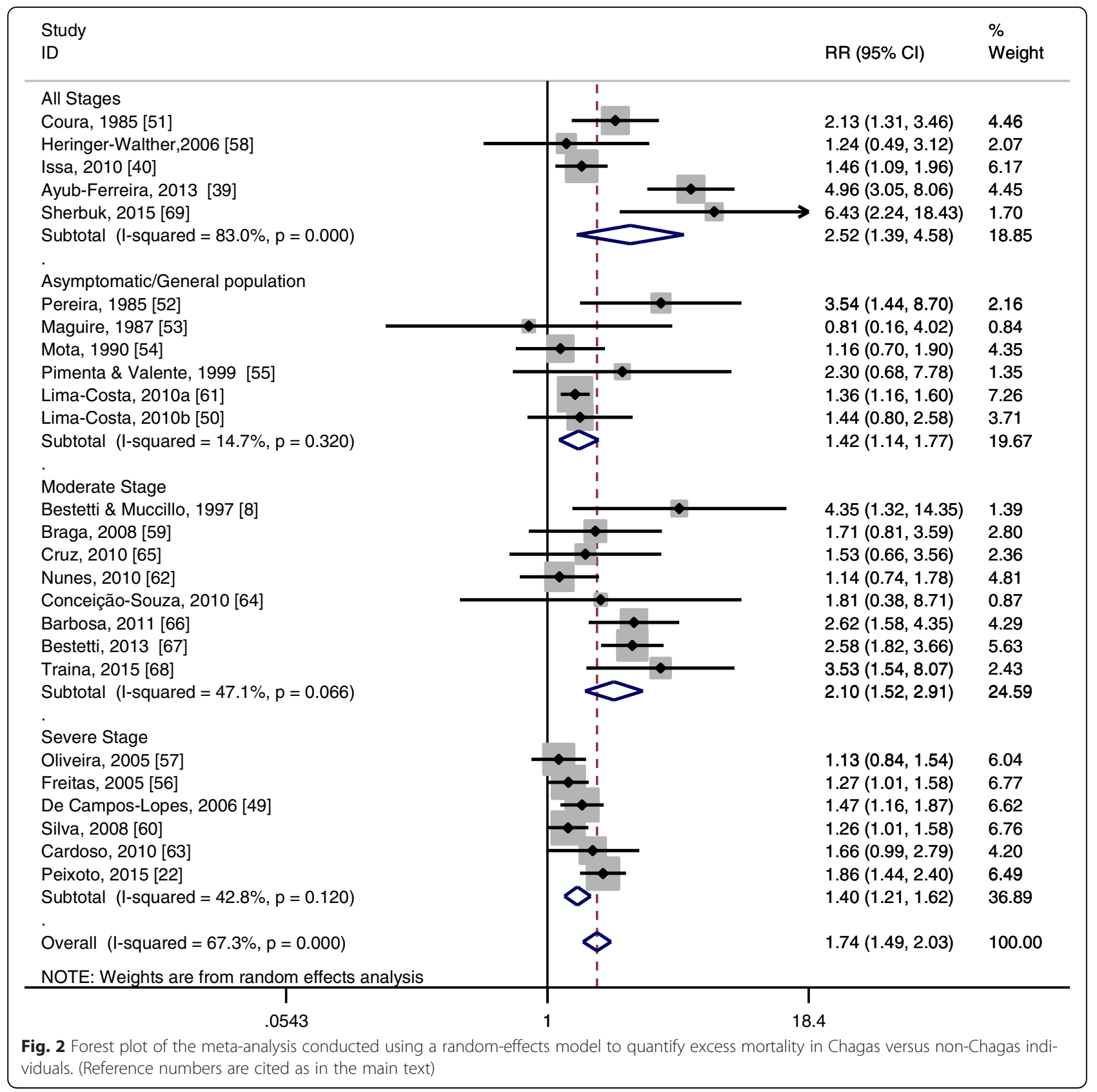

genotypes), excess mortality is not, once a given clinical/ symptomatic stage has been reached.

Some researchers have suggested that the poorer prognosis in chagasic patients compared to that in patients with other aetiologies, under a similar ventricular function, may be driven by the occurrence of malignant ventricular arrhythmias and consequently sudden death [38]. However, there is strong evidence suggesting that progressive heart failure has become more important than sudden death as the most common mode of death in Chagas disease, mainly as a consequence of the introduction of better anti-arrhythmic therapy, such as beta-blockers and devices [39]. Some studies suggest that the introduction of beta-blocker agents has attenuated the poor outcome of chagasic patients, making it similar to that of patients with other cardiac aetiologies [40]. We conjectured that this gradual therapeutic improvement could have influenced temporal trends of mortality in the two groups under comparison (Chagas and non-Chagas disease patients) $[39,41]$. We tested this hypothesis by exploring whether the effect size estimated changed according to the starting year of the study-a 


\section{Funnel plot with pseudo $95 \%$ confidence limits}

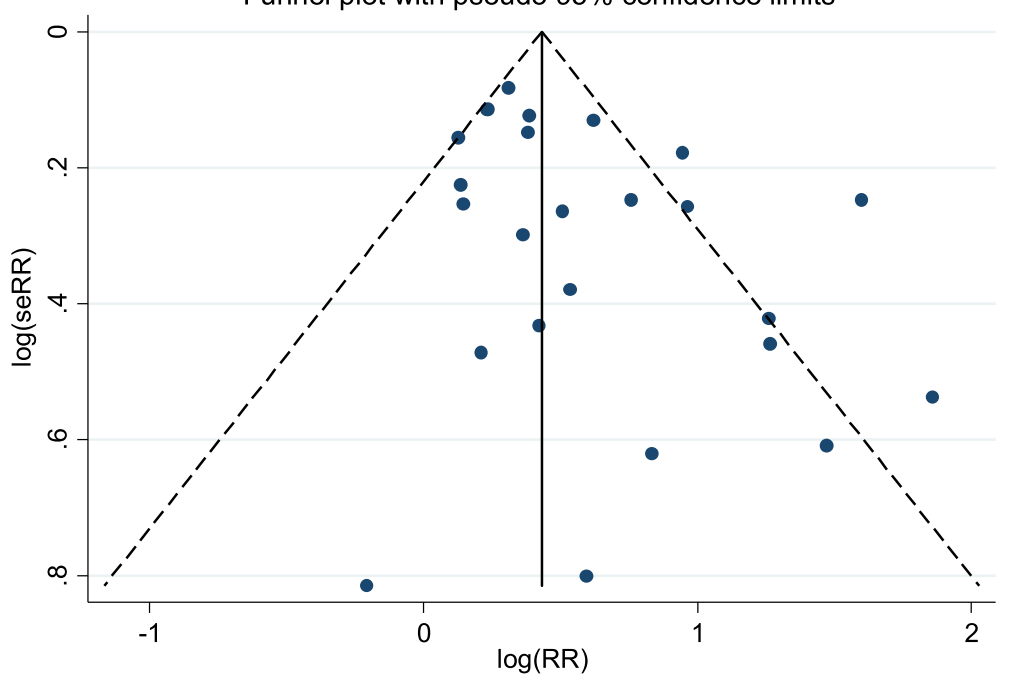

Fig. 3 Funnel plots of the logarithm of Relative Risk (log(RR)) for Egger's test of publication bias

proxy for potential improvement in prognosis derived from the introduction of better treatments over time. The meta-regression analysis did not find statistical differences between the two groups regarding this covariate, but this lack of evidence may be due to the paucity of good quality studies investigating predictors of mortality in Chagas disease patients and control groups.

Our study provides a strong evidence base to help inform the understanding of Chagas-associated mortality rates by researchers and practitioners in the field of Chagas disease. Thus far, although numerous data sources exist, no consensus on the operation and/or magnitude of mortality rates due to Chagas disease has been reached. Some studies looking at the dynamics of Chagas disease assume an excess mortality for a named determinate stage (i.e. rates of 0.10) [15], whereas others simply ignore the excess mortality [42]. A recent review by Nouvellet et al. [36], exploring different modelling approaches for Chagas disease, reported a lack of agreement between current models regarding inclusion of virulence and mortality due to $T$. cruzi infection, with mortality rates attributed to Chagas disease ranging between 0 and 0.30 , usually assigned to the final clinical stage of the disease [43]. Studies assessing the burden of disease and the cost effectiveness of interventions $[2,16,44]$ have considered excess mortality, with values ranging from 0.04 to 0.3 , depending on whether heart failure is included. These assumptions are critically relevant when linking transmission dynamics models and measures of incidence [45] to disease (morbidity-mortality) models in order to estimate burden of disease, calculate the contribution to DALYs due to Chagas, and quantify the cost-effectiveness of interventions. (see $[46,47]$ for an example of this crucial process in another NTD).

Our study indicates that much of the heterogeneity in the mortality rates quoted and used in the literature stems from a lack of agreement on clearly-defined disease stages. This results in mortality rates being calculated from already heterogeneous populations, leading to further confusion between rates of disease progression and mortality. By classifying Chagas patients using standard clinical stages used for other heart disease conditions (e.g. the NYHA classification), we attempted to bring coherence in the way disease progression and mortality can be defined and assessed. When evaluating Chagas disease burden, it will be necessary not only to consider the rates of Chagasassociated mortality (quantified here) but also the likely increased probability with which $T$. cruzi-infected patients progress from asymptomatic to moderate and to severe symptoms (e.g. NYHA I-II and NYHA III-IV respectively). While heart conditions typically develop with age, T. cruzi-infected patients are likely to develop heart disease earlier in their lives. Therefore, premature death due to Chagas must account for both the excess mortality in a particular clinical stage and the increased probability of progressing to such stage. While this study concerns the former, further research is needed to address the latter within a coherent framework to characterise rigorously rates of clinical progression in Chagas disease.

Finally, a large body of evidence suggests that socioeconomic status also influences the prognosis of cardiovascular disease [48]. A study investigating socioeconomic conditions and mortality in Brazil has shown that Chagas disease acts as a (clinical) predictor alongside socioeconomic situation [49]. However, as Chagas disease is mostly 
prevalent in poor populations, the independent contribution of these two factors and their interaction regarding the risk of mortality may be difficult to disentangle. One of the studies included in this review [43] found Chagas disease to be a predictor of all-cause mortality independently of socio-economic status [49]. Another study [50] found Chagas disease to be a predictor of mortality due to stroke after adjusting for educational status among other variables, with a $\mathrm{HR}=2.25$ (95\% CI 1.25-4.44), suggesting that Chagas disease is an independent contributor to mortality.

\section{Conclusions}

The systematic review and meta-analysis conducted in this study identified a consistent body of evidence indicating that Chagas disease is associated with statistically significant excess mortality. The relative risk was 1.74 (95 \% CI 1.49-2.03) and the attributable risk percent was $42.5 \%$. This excess mortality affected all Chagas disease patients regardless of their clinical presentation. Annual mortality rates increased with clinical severity. These results were robust to publication bias and variations in study quality. Heterogeneity in published mortality rates, and/or lack of recognition of the excess mortality, is likely to be due to heterogeneity (or absence) of clinical stage classification. Therefore, we advocate the use of a standardised system of disease severity such as the NYHA grading system (used here). Adoption of a well-characterised classification system will also help in the much needed estimation of rates of disease progression associated with T. cruzi infection. Our results have implications for the mathematical modelling, burden of disease estimation and economic evaluations of American trypanosomiasis and its control.

\section{Ethics approval and consent to participate Not applicable.}

\section{Additional files}

Additional file 1: PRISMA Checklist. (PDF $65 \mathrm{~kb}$ )

Additional file 2: Details on Methods and Analyses. (PDF 80 kb)

\footnotetext{
Abbreviations

AMR: annual mortality rate; ARP: attributable risk percent; Cl: confidence interval; DALY: disability-adjusted life year; df: degrees of freedom; ECG: electrocardiogram; HR: hazard ratio; NOS: Newcastle-Ottawa Scale; NTD: neglected tropical disease; NYHA: New York Heart Association Functional Classification; OR: odds ratio; PRISMA: Preferred Reporting Items for Systematic Reviews and Meta-Analyses; RR: relative risk (or risk ratio); YLL: years of life lost.
}

\section{Competing interests}

The authors declare that they have no competing interests.

\section{Authors' contributions}

Conceived and designed the study: ZMC, OO, PN, MGB; evaluated the studies and extracted the data: ZMC, OO; performed the analyses: ZMC, OO, $\mathrm{PN}$; wrote the paper: ZMC, OO, PN, MGB. All authors revised and approved the final version of the paper.

\section{Acknowledgements}

We thank the support of Dr Lesong Conteh (Health Economics Group) and of the London Centre for Neglected Tropical Disease Research, at Imperial College London. This work formed part of the final MSc in Epidemiology project of $\mathrm{OO}$ at the School of Public Health, Imperial College London.

\section{Funding statement}

This work was supported by the Departamento Administrativo Nacional de Ciencia y Tecnología de Colombia (COLCIENCIAS) through a PhD scholarship to ZMC [call 569]. PN was supported by the Medical Research Council and the Health Protection Research Units of the National Institute for Health Research. The funders had no role in study design, data collection and analysis, decision to publish, or preparation of the manuscript.

\section{Author details}

${ }^{1}$ London Centre for Neglected Tropical Disease Research (LCNTDR), Department of Infectious Disease Epidemiology, School of Public Health, Faculty of Medicine (St Mary's campus), Imperial College London, Norfolk Place, London W2 1PG, United Kingdom. ${ }^{2}$ Grupo de Parasitología - RED CHAGAS, Instituto Nacional de Salud, Bogotá, Colombia. ${ }^{3}$ Medical Research Council Centre for Outbreak Analysis and Modelling, Department of Infectious Disease Epidemiology, School of Public Health, Faculty of Medicine (St Mary's campus), Imperial College London, London, UK.

\section{Received: 23 November 2015 Accepted: 11 January 2016}

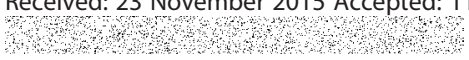

\section{References}

1. World Health Organization. Chagas disease in Latin America: an epidemiological update based on 2010 estimates. Wkly Epidemiol Rec. 2015;90:33-43.

2. Lee BY, Bacon KM, Bottazzi ME, Hotez PJ. Global economic burden of Chagas disease: a computational simulation model. Lancet Infect Dis. 2013;13:342-8.

3. Longo DL, Bern C. Chagas' Disease. N Engl J Med. 2015;373:456-66.

4. Rassi A, Marcondes de Rezende J. American trypanosomiasis (Chagas disease). Infect Dis Clin North Am. 2012;26:275-91.

5. Dias E, Laranja F, Miranda A, Nobrega G. Chagas' disease; a clinical, epidemiologic, and pathologic study. Circulation. 1956;14:1035-60.

6. Prata A. Clinical and epidemiological aspects of Chagas disease. Lancet Infect Dis. 2001;1:92-100.

7. Cunha-Neto E, Chevillard C. Chagas Disease Cardiomyopathy: Immunopathology and Genetics. Mediators Inflamm. 2014:2014:1-11.

8. Bestetti RB, Muccillo G. Clinical course of Chagas' heart disease: a comparison with dilated cardiomyopathy. Int J Cardiol. 1997;60:187-93.

9. Sabino EC, Ribeiro AL, Salemi VMC, Di Lorenzo-Oliveira C, Antunes AP, Menezes MM, et al. Ten-year incidence of Chagas cardiomyopathy among asymptomatic Trypanosoma cruzi-seropositive former blood donors. Circulation. 2013;127:1105-15.

10. Carod-Artal FJ, Vargas AP, Horan TA, Nunes LGN. Chagasic cardiomyopathy is independently associated with ischemic stroke in Chagas disease. Stroke. 2005;36:965-70.

11. Oliveira-Filho J, Viana LC, Vieira-de-Melo RM, Faical F, Torreao JA, Villar FAGA, et al. Chagas disease is an independent risk factor for stroke: baseline characteristics of a Chagas Disease cohort. Stroke. 2005;36:2015-7.

12. Hotez PJ, Alvarado M, Basáñez M-G, Bolliger I, Bourne R, Boussinesq M, et al. The global burden of disease study 2010: interpretation and implications for the neglected tropical diseases. PLoS Negl Trop Dis. 2014;8:e2865.

13. Tanowitz HB, Machado FS, Spray DC, Friedman JM, Weiss OS, Lora JN, et al. Developments in the management of Chagas cardiomyopathy. Expert Rev Cardiovasc Ther. 2015; 1-17. DOl:10.1586/14779072.2015.1103648.

14. Sousa GR, Costa HS, Souza AC, Nunes MCP, Lima MMO, Rocha MO. Health-related quality of life in patients with Chagas disease: a review of the evidence. Rev Soc Bras Med Trop. 2015;48:121-8. 
15. Peterson JK, Bartsch SM, Lee BY, Dobson AP. Broad patterns in domestic vector-borne Trypanosoma cruzi transmission dynamics: synanthropic animals and vector control. Parasit Vectors. 2015;8:537.

16. Lee BY, Bacon KM, Connor DL, Willig AM, Bailey RR. The potential economic value of a Trypanosoma cruzi (Chagas disease) vaccine in Latin America. PLoS Negl Trop Dis. 2010;4:e916.

17. Rassi A, Rassi SG. Predictors of mortality in chronic Chagas disease: a systematic review of observational studies. Circulation. 2007:115:1101-8.

18. De Souza ACJ, Salles G, Hasslocher-Moreno AM, de Sousa AS, AlvarengaAmericano do Brasil PE, Saraiva RM, et al. Development of a risk score to predict sudden death in patients with Chaga's heart disease. Int J Cardiol. 2015;187:700-4.

19. Rassi A, Rassi A, Little WC, Xavier SS, Rassi SG, Rassi AG, et al. Development and validation of a risk score for predicting death in Chagas' heart disease. N Engl J Med. 2006;355:799-808.

20. Linetzky B, Konfino J, Castellana N, De Maio F, Bahit MC, Orlandini A, et al. Risk of cardiovascular events associated with positive serology for Chagas: a systematic review. Int J Epidemiol. 2012;41:1356-66.

21. Moher D, Liberati A, Tetzlaff J, Altman DG. Preferred Reporting Items for Systematic Reviews and Meta-Analyses: The PRISMA Statement. PLoS Med. 2009;6:e1000097.

22. Peixoto G, Siqueira S, Martins S, Santos J, Nishioka S, Teixeira R, et al. Cardiac resynchronization therapy in Chagas cardiomyopathy. In Europace. Volume 17; 2015:iii151.

23. GA Wells, Shea B, O'Connell D, Peterson JEA, Welch V, Losos M, Tugwell P. The Newcastle-Ottawa Scale (NOS) for assessing the quality of nonrandomised studies in meta-analyses. Available: [http://www.ohri.ca/ programs/clinical_epidemiology/oxford.asp], accessed 23 November 2015.

24. Higgins JPT, Thompson SG, Deeks JJ, Altman DG. Measuring inconsistency in meta-analyses. Br Med J. 2003:327:557-60.

25. Thompson SG, Sharp SJ. Explaining heterogeneity in meta-analysis: a comparison of methods. Stat Med. 1999;18:2693-708.

26. Baker WL, White CM, Cappelleri JC, Kluger J, Coleman Cl, Health Outcomes, Policy, and Economics (HOPE) Collaborative Group. Understanding heterogeneity in meta-analysis: the role of meta-regression. Int J Clin Pract. 2009;63:1426-34

27. Egger M, Davey-Smith G, Schneider M, Minder C. Bias in meta-analysis detected by a simple, graphical test. Br Med J. 1997;315:629-34.

28. Sterne J, Harbord R. Funnel plots in meta-analysis. Stata J. 2004:4:127-41.

29. Duval S, Tweedie R. Trim and fill: A simple funnel-plot-based method of testing and adjusting for publication bias in meta-analysis. Biometrics. 2000;56:455-63.

30. Arribada A, Apt W, Ugarte JM. Evolución de la cardiopatía chagásica durante un período de cuatro años en un grupo de pacientes chilenos. Bol Of Sanit Panam. 1987;102:49-73.

31. Rassi S, Carlos A, Barretto P, Porto CC, Pereira CR, Calaça BW, et al. Survival and prognostic factors in systolic heart failure with recent symptom onset. Arq Bras Cardiol. 2004;84:1-5.

32. Puigbó JJ, Nava-Rhode JR, Garcia-Barrios H, Gil-Yepez C. A 4-year follow-up study of a rural community with Chagas' disease. Bull World Health Organ. 1968;39:341-8

33. Lauria-Pires L, Braga MS, Vexenat AC, Nitz N, Simões-Barbosa A, Tinoco DL, et al. Progressive chronic Chagas heart disease ten years after treatment with anti-Trypanosoma cruzi nitroderivatives. Am J Trop Med Hyg. 2000;63:111-8.

34. Nunes VL, Ramires FJA, Pimentel WDS, Fernandes F, lanni BM, Mady C. The role of storage of interstitial myocardial collagen on the overlife rate of patients with idiopathic and chagasic dilated cardiomyopathy. Arq Bras Cardiol. 2006;87:693-8

35. Espinosa R, Carrasco HA, Belandria F, Fuenmayor AM, Molina C, González R, et al. Life expectancy analysis in patients with Chagas' disease: prognosis after one decade (1973-1983). Int J Cardiol. 1985;8:45-56.

36. Basquiera AL, Sembaj A, Aguerri AM, Omelianiuk M, Guzmán S, MorenoBarral J, et al. Risk progression to chronic Chagas cardiomyopathy: influence of male sex and of parasitaemia detected by polymerase chain reaction. Heart. 2003;89:1186-90.

37. Messenger LA, Miles MA, Bern C. Between a bug and a hard place: Trypanosoma cruzi genetic diversity and the clinical outcomes of Chagas disease. Expert Rev Anti Infect Ther. 2015;13:995-1029.

38. Veloso $\mathrm{HH}$. Incidence of sudden cardiac death in congestive heart failure: Chagas disease versus systemic arterial hypertension. Int J Cardiol. 2009;175:175-6.

39. Ayub-Ferreira SM, Mangini S, Issa VS, Cruz FD, Bacal F, Guimarães GV, et al. Mode of death on Chagas heart disease: comparison with other etiologies. a subanalysis of the REMADHE prospective trial. PLoS Negl Trop Dis. 2013;7:e2176.
40. Issa VS, Amaral AF, Cruz FD, Ferreira SMA, Guimaraes GV, Chizzola PR, et al. Beta-blocker therapy and mortality of patients with chagas cardiomyopathy: a subanalysis of the REMADHE prospective trial. Circ Heart Fail. 2010;3:82-8.

41. Adamson PB, Gilbert EM. Reducing the risk of sudden death in heart failure with beta-blockers. J Card Fail. 2006;12:734-46.

42. Pelosse P, Kribs-Zaleta CM, Ginoux M, Rabinovich JE, Gourbière S, Menu F. Influence of vectors' risk-spreading strategies and environmental stochasticity on the epidemiology and evolution of vector-borne diseases: the example of Chagas' disease. PLoS One. 2013;8:e70830.

43. Nouvellet P, Cucunubá ZM, Gourbière S. Ecology, evolution and control of Chagas disease: a century of neglected modelling and a promising future. In Mathematical Models for Neglected Tropical Diseases: Essential Tools for Control and Elimination, Part A (Anderson RM \& Basáñez MG, editors). Adv Parasitology. 2015;87:135-91.

44. Wilson LS, Strosberg AM, Barrio K. Cost-effectiveness of Chagas disease interventions in Latin America and the Caribbean: Markov models. Am J Trop Med Hyg. 2005;73:901-10.

45. Cucunubá ZM, Nouvellet $P$, Conteh L, Basáñez MG. Temporal and regional trends of force infection of Chagas disease in Colombia. Am J Trop Med Hyg. 2014;91 Suppl 5:374.

46. Turner HC, Walker M, Churcher TS, Basáñez MG. Modelling the impact of ivermectin on River Blindness and its burden of morbidity and mortality in African Savannah: EpiOncho projections. Parasit Vectors. 2014;7:241.

47. Turner HC, Walker M, Churcher TS, Osei-Atweneboana MY, Biritwum NK, Hopkins A, et al. Reaching the London Declaration on Neglected Tropical Diseases goals for onchocerciasis: an economic evaluation of increasing the frequency of ivermectin treatment in Africa. Clin Infect Dis. 2014;59:923-32.

48. Clark AM, DesMeules M, Luo W, Duncan AS, Wielgosz A. Socioeconomic status and cardiovascular disease: risks and implications for care. Nat Rev Cardiol. 2009:6:712-22.

49. de Campos Lopes CB, Yamada AT, Araújo F, Pereira-Barreto AC, Mansur AJ. Socioeconomic factors in the prognosis of heart failure in a Brazilian cohort Int J Cardiol. 2006;113:181-7.

50. Lima-Costa MF, Matos DL, Ribeiro ALP. Chagas disease predicts 10-year stroke mortality in community-dwelling elderly: The Bambui Cohort Study of Aging. Stroke. 2010;41:2477-82.

51. Coura JR, de Abreu LL, Pereira JB, Willcox HP. Morbidity in Chagas' disease. IV. Longitudinal study of 10 years in Pains and Iguatama, Minas Gerais, Brazil. Mem Inst Oswaldo Cruz. 1985;80:73-80 (In Portuguese).

52. Pereira JB, Willcox HP, Coura JR. Morbidity in Chagas' disease. III. Longitudinal study of 6 years, in Virgem da Lapa, MG, Brazil. Mem Inst Oswaldo Cruz. 1985;80:63-71 (In Portuguese).

53. Maguire JH, Hoff R, Sherlock I, Guimaraes AC, Sleigh AC, Ramos NB, et al. Cardiac morbidity and mortality due to Chagas' disease: prospective electrocardiographic study of a Brazilian community. Circulation. 1987;75:1140-5.

54. Mota EA, Guimarães AC, Santana OO, Sherlock I, Hoff R, Weller TH. A nine year prospective study of Chagas' disease in a defined rural population in northeast Brazil. Am J Trop Med Hyg. 1990;42:429-40.

55. Pimenta J, Valente N. Evolução clínica a longo prazo, correlacionando a presença de bloqueios da condução intraventricular em pacientes chagásicos e não chagásicos assintomáticos. Rev Soc Bras Med Trop. 1999:32:621-31.

56. Freitas HFG, Chizzola PR, Paes ÂT, Lima ACP, Mansur AJ. Risk stratification in a Brazilian hospital-based cohort of 1220 outpatients with heart failure: role of Chagas' heart disease. Int J Cardiol. 2005;102:239-47.

57. de Oliveira MT, Canesin MF, Munhoz RT, del Carlo CH, Scipioni A, Ramires JAF, et al. Major clinical characteristics of patients surviving 24 months or more after hospitalization due to decompensated heart failure. Arq Bras Cardiol. 2005;84:161-6. In Portuguese.

58. Heringer-Walther S, Moreira MDCV, Wessel N, Wang Y, Ventura TM, Schultheiss HP, et al. Does the C-type natriuretic peptide have prognostic value in Chagas disease and other dilated cardiomyopathies? J Cardiovasc Pharmacol. 2006:48:293-8.

59. Braga JCV, Reis F, Aras R, Dantas N, Bitencourt A, Neves FS, et al. Is Chagas cardiomyopathy an independent risk factor for patients with heart failure? Int J Cardiol. 2008;126:276-8.

60. Silva $\mathrm{CP}$, del Carlo $\mathrm{CH}$, de Oliveira Junior MT, Scipioni A, Strunz-Cassaro C, et al. Why do patients with chagasic cardiomyopathy have worse outcomes than those with non-chagasic cardiomyopathy? Arq Bras Cardiol. 2008;91:358-62.

61. Lima-Costa MF, Peixoto SV, Ribeiro ALP. Chagas disease and mortality in old age as an emerging issue: 10 year follow-up of the Bambuí populationbased cohort study (Brazil). Int J Cardiol. 2010;145:362-3. 
62. Pereira Nunes MC, Barbosa MM, Ribeiro ALP, Amorim Fenelon LM, Rocha MOC. Predictors of mortality in patients with dilated cardiomyopathy: relevance of Chagas disease as an etiological factor. Rev Esp Cardiol. 2010;63:788-97.

63. Cardoso J, Novaes M, Ochiai M, Regina K, Morgado P, Munhoz R, et al. Chagas cardiomyopathy: prognosis in clinical and hemodynamic profile $C$. Arq Bras Cardiol. 2010;95:518-23.

64. Conceição-Souza GE, Pessoa de Melo LM, Vieira JL, Batistela V, Gorobets E, Valim LR, et al. Prognosis of Chagas' cardiomyopathy versus nonChagas' cardiomyopathy in beta-blockers era: 24 month follow-up. Eur Heart J. 2010;31:130

65. Cruz FD, Ferreira SA, Issa VS, Bocchi EA. Components of life quality evaluation in heart failure clinic. Eur J Heart Fail. 2014;16 Suppl 2:179.

66. Barbosa AP, Cardinalli-Neto A, Otaviano AP, Rocha BF, Bestetti RB. Comparison of outcome between Chagas cardiomyopathy and idiopathic dilated cardiomyopathy. Arq Bras Cardiol. 2011:97:517-25.

67. Bestetti RB, Otaviano AP, Fantini JP, Cardinalli-Neto A, Nakazone MA, Nogueira PR. Prognosis of patients with chronic systolic heart failure: Chagas disease versus systemic arterial hypertension. Int J Cardiol. 2013;168:2990-1.

68. Traina MI, Sanchez DR, Hernandez S, Bradfield JS, Labedi MR, Ngab TA, et al. Prevalence and impact of Chagas disease among Latin American immigrants with nonischemic cardiomyopathy in Los Angeles. California Circ Heart Fail. 2015;8:938-43.

69. Sherbuk JE, Okamoto EE, Marks MA, Fortuny E, Clark EH, Galdos-Cardenas G, et al. Biomarkers and mortality in severe Chagas cardiomyopathy. Glob Heart. 2015;10:173-80.

\section{Submit your next manuscript to BioMed Central and we will help you at every step:}

- We accept pre-submission inquiries

- Our selector tool helps you to find the most relevant journal

- We provide round the clock customer support

- Convenient online submission

- Thorough peer review

- Inclusion in PubMed and all major indexing services

- Maximum visibility for your research

Submit your manuscript at www.biomedcentral.com/submit 